\title{
Study of the Dynamics of Quaternary Aquifers by Infiltration of Rainwater and/or Lake Chad
}

\author{
BADA Ali Malloum*, MALOU Raymond, KODI Mahamat Mbâm, SOUK Allag Waayna \\ Department of Geology Mailbox, Faculty of Science and Technology, Cheikh Anta Diop University, \\ Laboratory of Hydrochemistry and Hydrology, 5005 Dakar, Fann \\ *Corresponding author: badafils@gmail.com
}

\begin{abstract}
Lake Chad is an expanse of water that supports millions of people. Its excessive narrowing, or even its total disappearance, would lead to a large migration of populations, called climatic refugees. The collections of the dynamic monitoring of the quaternary phreatic aquifers over four years, the water level induced deductions provided data on the changes in the dynamic levels of the free water table due to the variation in lake water levels. The Lake Chad region, which is an arid to sub arid territory with a Sahel-Saharan climate, where water resources are under climatic and anthropogenic pressure. If we consider a desert climate zone where rains are rather scarce, we will have more stable groundwater. The aridity does not have a major impact on the resources of the dune sands aquifer, despite the almost total absence of rainfall. Surface waters have been severely reduced due to different periods of drought [1]. The study of the dynamics of the Quaternary aquifer by infiltration of rainwater and / or Lake Chad, provide us with clarification on the exchanges between the waters and the Quaternary aquifer. The theoretical and methodological approaches have given rise to spatiotemporal fluctuations of the dynamic level. The main observations observed, that there is a hydrodynamic variation of groundwater. The relationships between the water table and the surface waters could thus be clarified. This will eventually allow for alternative use of water resources.
\end{abstract}

Keywords: narrowing, dynamic follow-ups, open water tables, water levers, water heights, quaternary aquifers, Lake Chad

Cite This Article: BADA Ali Malloum, MALOU Raymond, KODI Mahamat Mbâm, and SOUK Allag Waayna, "Study of the Dynamics of Quaternary Aquifers by Infiltration of Rainwater and/or Lake Chad." American Journal of Water Resources, vol. 5, no. 2 (2017): 41-53. doi: 10.12691/ajwr-5-2-3.

\section{Introduction}

Ground waters are playing everywhere, an important role in the availability of water resources. Underground aquifers represent the most stable element of surface flow. This shows that there is no clear boundary between groundwater and surface water resources, that water flows underground or above ground depending on certain parameters, the most important of which are relief and vegetation cover.

The Lake Chad region, which is an arid to Sub arid territory with a Sahel-Saharan climate, where geological formations are predominantly coarse to medium sands, silts and clays sometimes mixed from one site to another and in depth, Where surface water is under climatic and anthropogenic pressure, so groundwater is a reliable source of water. They have a regulatory function during periods of insufficient precipitation [2].

In addition, since 1973, surface water has been severely reduced due to different periods of drought. The narrowing of the surface of the lake gives rise to reserves of water in the shallows, some of which are linked by arms of the lake surface waters. These reserves of water are called polders, lake bottoms etc. This makes possible the survival of the surrounding regions if the conditions of existence of the lake were to aggravate one day very drastically.

The Quaternary aquifer of the Chadian basin covers an area of more than $500,000 \mathrm{~km} 2$ and includes all superficial aquifers of the lake region and occupies the center of the Chadian basin and separates from the underlying artesian Pliocene aquifer by the intermediary of a thick clay layer and also by the existence of a deep aquifer of 600 meters [3]

Silting is also a factor contributing to the decline in the depth of Lake Chad.

The evaporation of the waters of Lake Chad is closely linked to the climatic variation that goes from heat to cold, thus conditioning the amount of water evaporation. The hotter the water, the greater the amount of water that evaporates. On the other hand, during cold periods, the amount of evaporation is very small [4].

The level of the lake rises when the quantity of water evaporated is less than the quantity introduced by the tributaries. Infiltrations are more or less compensated by the rains on the lake.

The relationship between Lake Chad and the aquifers of the inter-dune shallows in the region depends on the contributions of tributaries and meteoric waters, which are the basis of several problems that need to be addressed in order to safeguard the Chadian basin. Among these problems we have the question of the alimentation and the diversity of the aquifers that supply Lake Chad. 
The objective of this work is to understand the relationship between rainfall and lake water in the Lake Chad region.

The work you have in your hands is a framework for the dynamic evolution of the upper and later quaternary aquifers through the infiltration of rainwater and the lake, followed by a discussion and a conclusion.

\section{Materials and METHODS}

\subsection{Materials}

\subsubsection{Probe}

Ideal for measuring the depth of water in water lever tubes, wells and boreholes: Water level measuring probes include a stainless steel probe with a flexible graduated cable, manually wound on a winder containing a solid state switched circuit, a sound indicator and a battery.

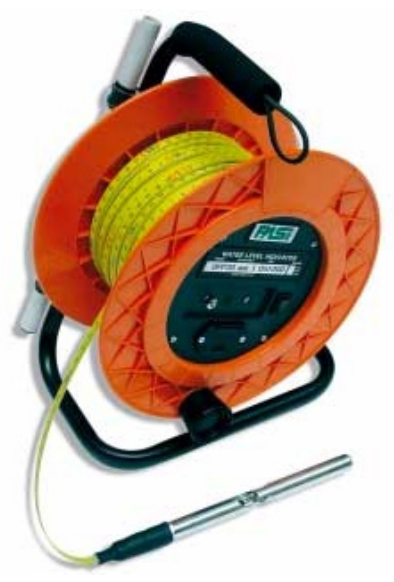

Figure 1. Water level sensor

The probe comprises an insulated space which acts as a switch, the circuit being closed by contact with water. Inside the manual winder there is a sensitivity control which is adjusted according to the conductivity of the water.

The cable comprises a non-elastic flat ribbon with stranded steel conductors, graduated $1 \mathrm{~mm}$ apart.

\subsubsection{Characteristics of the probe}

- Ability to take measurements at multiple locations with one instrument;

- Flat ribbon for precise measurements;

- 500 meter ribbon with $1 \mathrm{~mm}$ graduations;

- Soft and easy to carry

- Adjustment in case of variations in water conductivity;

- Sound signal to warn the detection of water levels;

- Ribbon shape preventing it from sticking to wet surfaces.

\subsubsection{Limnimetry}

The measurement of water heights or the variation of a water body is generally carried out discontinuously by reading a graduated scale (limnometric scale) fixed on a support, these are installed, used in Bol for water height measurements (Figure 7)

\subsubsection{Global Position System (GPS)}

The GPS functions by calculating the distance that separates a GPS receiver from several satellites (by the principle of triangulation). The required information to calculate the position of satellites is regularly transmitted to the receiver, and that can, according to its acquaintance to the distance separating it from the satellites, know its coordinates (Figure 2).

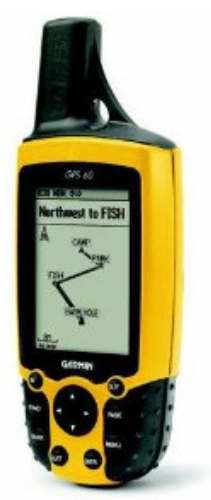

Figure 2. Field GPS

\subsection{Methods}

\subsubsection{Probe}

Apart from the two polder wells of Mamdi, the remaining water level measurements in the aquifers are carried out in the manual boreholes (Figure 3).

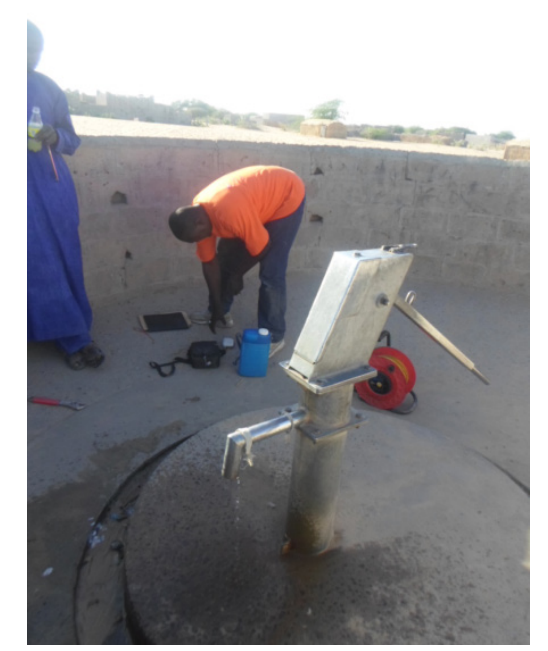

Figure 3. Boreholes used for water level measurements

It is therefore important, first of all, to specify the level of water in the aquifer in a hydrogeological study. Measured water levels are rarely constant over a long period of time; they are subject to variations due to:

1) Precipitation, infiltration and evaporation,

2) The variation of the stress level (loads),

3) The seasonal flow supplied by the seasonal variation of the levels of neighboring rivers or lakes,

4) Pumping or recharging water,

5) Effects of freezing and thawing,

6) Moisture.

Devices such as boreholes, wells and piezometers are generally used to perform measurements. 


\subsubsection{Principles for measuring the water level of aquifers}

The measurement of the water level is carried out by a water level detector which is lowered into the wellbore tube, at each measurement.

When the probe reaches the surface of the water, an electrical contact is established between the electrodes, triggering an audible signal. The depth can then be read on the graduated ribbon, it must be noted to have the actual depth of the level of water in the aquifer, it is necessary to differentiate the depth minus the margin here for the manual drilling, the outer tube above the ground is fixed and therefore the tubing of the pump is hooked and also a rod for the movement of the water drainage of the water table (Figure 3).

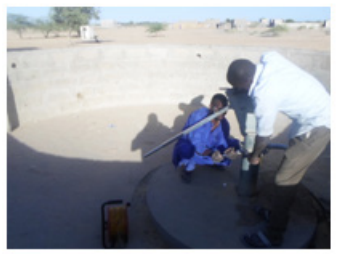

a) Unbolt the casing of the curb.

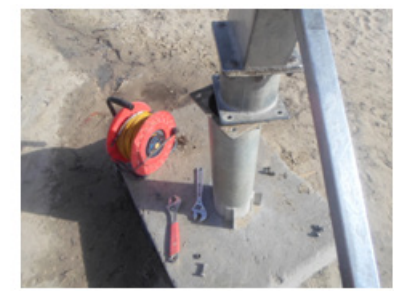

b) Move the upper part, drilling Leaving space to introduce the probe.
Figure 4. Level measurement steps by a probe in the field

\subsubsection{Limnimetry}

Limnimetry is the basic element of water level readings; it is most often constituted by a limnometric scale which is a ruler or a graduated stem of metal (possibly made of wood or stone), placed vertically (Figure 7) Allowing direct reading of the height of water at the station. The limnometric scale is read at the nearest half centimeter. The zero point of the limnometric scale ( 271 meters at Bol) must be placed below the lowest water possible under the conditions of maximum digging of the bed in the control section, in order not to have negative quotations.

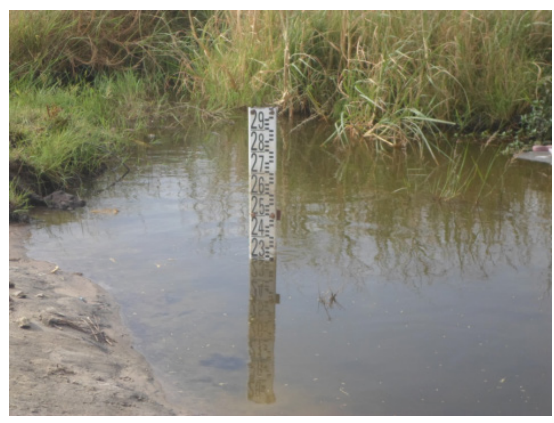

Figure 5. One of the limnometric scales installed in Bol (northeast of Lake Chad)

\section{Results}

Lake Chad is shared by four riparian countries: Cameroon, Niger, Nigeria and Chad; From the geomorphological point of view it is subdivided into two large basins separated by a high ground called the Great Barrier [5].

The basin of the lake is divided into a basin north and south, the latter constituting our study area is located in the territory of Chad (Figure 6).

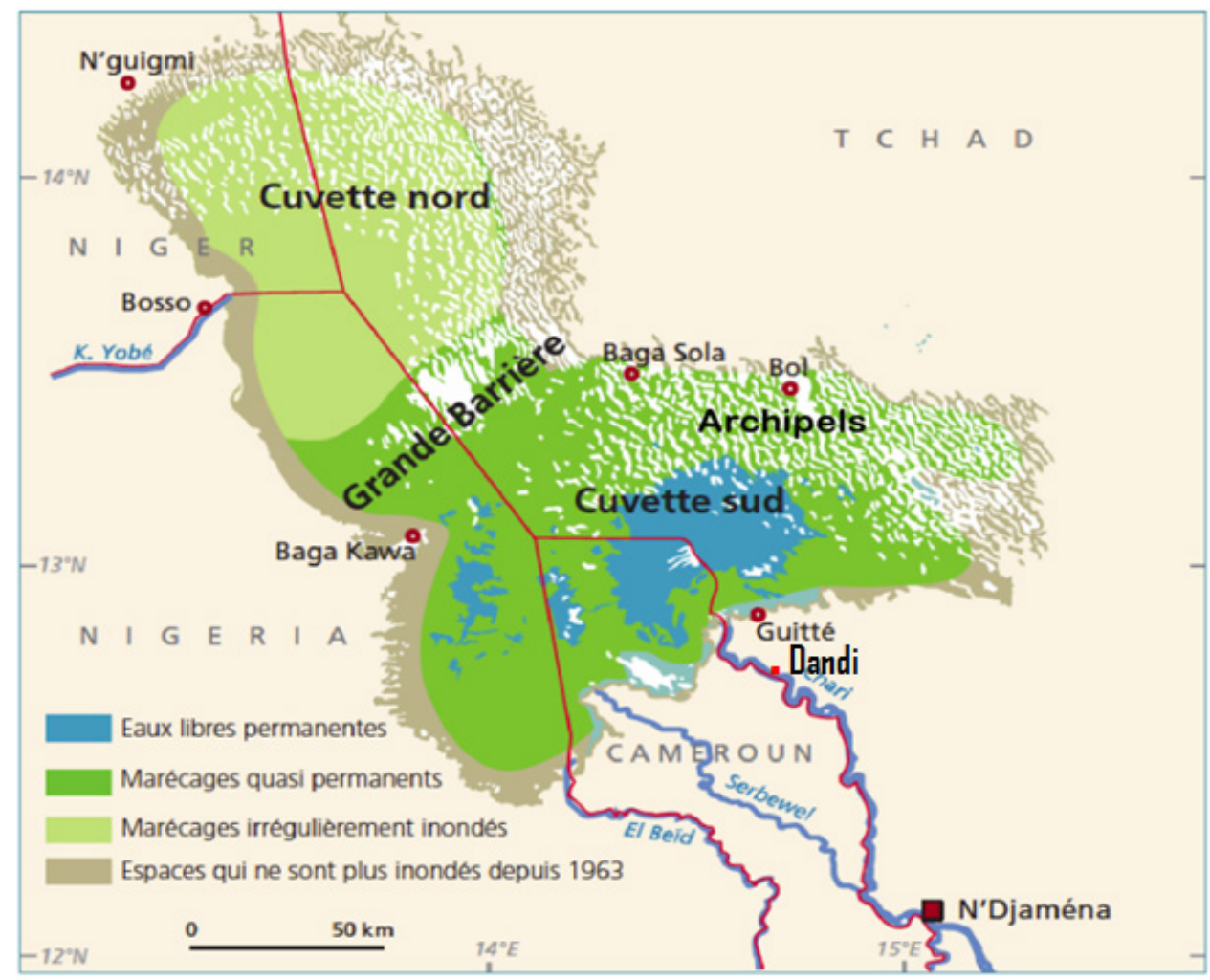

Blue: permanent open water, Green: Quasi-permanent marshes, Light green: Irregularly flooded marshes, Grey: areas that have been no more flooded since 1963

Figure 6. Schematic map showing the two distinct basins of Lake Chad in the southern basin (the observation sites of the measurements: Bol, Baga-sola, Guitte and Dandi) and the northern basin separated by the great barrier line Baga kawa - Baga Sola over a width of $40 \mathrm{~km}$ [5] 
Table 1. The sites of the measurements and the geographical coordinates of the various boreholes and wells of the observation points

\begin{tabular}{|c|c|c|c|c|c|c|c|c|c|c|c|c|}
\hline \multirow{2}{*}{ Sites } & \multirow{2}{*}{$\begin{array}{l}\text { Measured } \\
\text { structures }\end{array}$} & \multicolumn{3}{|c|}{ Geographical coordinates } & \multicolumn{5}{|c|}{ ers measured in the field $\left(29-30^{\circ} \mathrm{C}\right.$ January } & \multicolumn{2}{|c|}{$\begin{array}{l}\text { Parameters taken } \\
\text { from drilling data } \\
\text { sheets }\end{array}$} & \multirow{2}{*}{\begin{tabular}{|l} 
Observations \\
\end{tabular}} \\
\hline & & Latitudes & Longitudes & $\begin{array}{c}\text { Altitude } \\
\mathrm{s}\end{array}$ & $\mathrm{m} / \mathrm{cm}$ & $\mathrm{ppm}$ & $\mathrm{pH}$ & \multicolumn{2}{|c|}{$\begin{array}{l}\text { Depths of the water level in the aquifer } \\
\text { (meters) NS }\end{array}$} & $\begin{array}{c}\text { Pump } \\
\text { depths } \\
\text { (m) }\end{array}$ & \begin{tabular}{|c|}
$\begin{array}{c}\text { Drilling } \\
\text { depths } \\
(\mathrm{m})\end{array}$ \\
\end{tabular} & \\
\hline \multirow{8}{*}{ Bol } & $\begin{array}{c}\mathrm{W}_{1} \\
\text { (polder of } \\
\text { Nguini) }\end{array}$ & $13^{\circ} 31603 \mathrm{~N}$ & $014^{\circ} 41314 \mathrm{E}$ & $276 \mathrm{~m}$ & 0,26 & 201 & 6,00 & 02,90 (January 2013) & 01,50 (January 2015) & \multicolumn{2}{|c|}{ - } & $\begin{array}{l}\text { running of } \\
\text { water in the } \\
\text { rainy season }\end{array}$ \\
\hline & $\mathrm{D}_{1}$ & $13^{\circ} 31324 \mathrm{~N}$ & $014^{\circ} 41023 \mathrm{E}$ & $291 \mathrm{~m}$ & 0,42 & 292 & 6,40 & 11,80 (January 2013) & 09,70 (January 2015) & $20 \mathrm{~m}$ & $25 \mathrm{~m}$ & \\
\hline & $\mathrm{D}_{2}$ & $13^{\circ} 20079 \mathrm{~N}$ & $014^{\circ} 41736 \mathrm{E}$ & $293 \mathrm{~m}$ & 1,60 & 957 & 6,70 & 15,20 (January 2013 & 13,50 (January 2015) & $30 \mathrm{~m}$ & $35 \mathrm{~m}$ & \\
\hline & $\mathrm{D}_{3}$ & $13^{\circ} 28089 \mathrm{~N}$ & $014^{\circ} 42927 \mathrm{E}$ & $294 \mathrm{~m}$ & 1,40 & 902 & 6,60 & 14,00 (January 2013) & 12,00 (January 2015) & $30 \mathrm{~m}$ & $35 \mathrm{~m}$ & \\
\hline & $\mathrm{D}_{4}$ & $13^{\circ} 28043 \mathrm{~N}$ & $014^{\circ} 42794 \mathrm{E}$ & $293 \mathrm{~m}$ & 1,14 & 817 & 6,90 & 13,50 (January 2013) & 11,80 (January 2015) & $25 \mathrm{~m}$ & $30 \mathrm{~m}$ & \\
\hline & $\mathrm{D}_{5}$ & $13^{\circ} 27884 \mathrm{~N}$ & $014^{\circ} 42943 \mathrm{E}$ & $297 \mathrm{~m}$ & 1,42 & 911 & 6,90 & 14,50 (January 2013) & 12,50 (January 2015) & $30 \mathrm{~m}$ & $35 \mathrm{~m}$ & \\
\hline & $D_{6}$ & $13^{\circ} 27899 \mathrm{~N}$ & $014^{\circ} 42927 \mathrm{E}$ & $290 \mathrm{~m}$ & 1,14 & 817 & 6,80 & 13,00 (January 2013) & 10,90 (January 2015) & $25 \mathrm{~m}$ & $30 \mathrm{~m}$ & \\
\hline & $\begin{array}{c}\mathrm{W}_{2} \\
\text { (polder of } \\
\text { Mamdi) } \\
\end{array}$ & $13^{\circ} 25938 \mathrm{~N}$ & $014^{\circ} 44113 \mathrm{E}$ & $272 \mathrm{~m}$ & 1,34 & 882 & 6,80 & 00,80(January 2013) & 00,00 (January 2015) & . & - & $\begin{array}{l}\text { Running of } \\
\text { water in the } \\
\text { rainy season }\end{array}$ \\
\hline \multirow{4}{*}{$\begin{array}{c}\text { Baga- } \\
\text { sola }\end{array}$} & $\mathrm{D}_{7}$ & $13^{\circ} 32030 \mathrm{~N}$ & $014^{\circ} 18948 \mathrm{E}$ & $287 \mathrm{~m}$ & 0,77 & 560 & 6,80 & 13,80 (January 2013) & 11,60 (January 2015) & $25 \mathrm{~m}$ & $30 \mathrm{~m}$ & $\begin{array}{c}\text { Water brown } \\
\text { color }\end{array}$ \\
\hline & $\mathrm{D}_{8}$ & $13^{\circ} 32030 \mathrm{~N}$ & $014^{\circ} 18874 \mathrm{E}$ & $281 \mathrm{~m}$ & 0,50 & 357 & 6,70 & 11,00 (January 2013) & 10,00 (January 2015) & $20 \mathrm{~m}$ & $25 \mathrm{~m}$ & \\
\hline & $\mathrm{D}_{9}$ & $13^{\circ} 32395 \mathrm{~N}$ & $014^{\circ} 18540 \mathrm{E}$ & $278 \mathrm{~m}$ & 0,29 & 209 & 6,40 & 06,80 (January 2013) & 04,40 (January 2015) & $10 \mathrm{~m}$ & $15 \mathrm{~m}$ & \\
\hline & $\mathrm{D}_{10}$ & $13^{\circ} 32176 \mathrm{~N}$ & $014^{\circ} 19291 \mathrm{E}$ & $287 \mathrm{~m}$ & 1,22 & 842 & 6,70 & 17,60 (January 2013) & 14,80 (January 2015) & $25 \mathrm{~m}$ & $30 \mathrm{~m}$ & $\begin{array}{c}\text { Water: } \\
\text { clayey taste } \\
\text { and odor }\end{array}$ \\
\hline \multirow{4}{*}{ Dandi } & $D_{11}$ & $12^{\circ} 38789 \mathrm{~N}$ & $014^{\circ} 49812 \mathrm{E}$ & $293 \mathrm{~m}$ & 0,17 & 821 & 6,90 & 12,85 (January 2013) & 10,20 (January 2015) & $25 \mathrm{~m}$ & $30 \mathrm{~m}$ & \\
\hline & $D_{12}$ & $12^{\circ} 44018 \mathrm{~N}$ & $014^{\circ} 40880 \mathrm{E}$ & $288 \mathrm{~m}$ & 0,12 & 124 & 6,80 & 08,85 (January 2013) & 06,20 (January 2015) & $15 \mathrm{~m}$ & $20 \mathrm{~m}$ & Clayey taste \\
\hline & $\mathrm{D}_{13}$ & $12^{\circ} 47637 \mathrm{~N}$ & $014^{\circ} 40445 \mathrm{E}$ & $292 \mathrm{~m}$ & 2,30 & 1571 & 9,20 & 16,50 (January 2013) & 14,20 (January 2015) & $35 \mathrm{~m}$ & $40 \mathrm{~m}$ & \multirow{2}{*}{$\begin{array}{l}\text { Taste too } \\
\text { natron, the } \\
\text { people } \\
\text { complain. }\end{array}$} \\
\hline & $\mathrm{D}_{14}$ & $12^{\circ} 48075 \mathrm{~N}$ & $014^{\circ} 40825 \mathrm{E}$ & $290 \mathrm{~m}$ & 2,20 & 1492 & 9,10 & 15,00 (January 2013) & 13,00 (January 2015) & $35 \mathrm{~m}$ & $40 \mathrm{~m}$ & \\
\hline \multirow{5}{*}{ Guitté } & $\mathrm{D}_{15}$ & $12^{\circ} 52842 \mathrm{~N}$ & $014^{\circ} 39054 \mathrm{E}$ & $290 \mathrm{~m}$ & 0,90 & 612 & 6,50 & 09,00 (January 2013) & 06,30 (January 2015) & $15 \mathrm{~m}$ & $20 \mathrm{~m}$ & $\begin{array}{c}\text { Taste of the } \\
\text { natron }\end{array}$ \\
\hline & $\mathrm{D}_{16}$ & $12^{\circ} 53454 \mathrm{~N}$ & $014^{\circ} 38362 \mathrm{E}$ & $289 \mathrm{~m}$ & 0,30 & 302 & 6,20 & 07,80 (January 2013) & 05,20 (January 2015) & $15 \mathrm{~m}$ & $20 \mathrm{~m}$ & \\
\hline & $\mathrm{D}_{17}$ & $12^{\circ} 53511 \mathrm{~N}$ & $014^{\circ} 37799 \mathrm{E}$ & $281 \mathrm{~m}$ & 0,30 & 302 & 6,20 & 06,80 (January 2013) & 04,20(January 2015) & $15 \mathrm{~m}$ & $20 \mathrm{~m}$ & \\
\hline & $\mathrm{D}_{18}$ & $12^{\circ} 53409 \mathrm{~N}$ & $014^{\circ} 38035 \mathrm{E}$ & $285 \mathrm{~m}$ & 1,20 & 838 & 6,80 & 08,00(January 2013) & 06,00(January 2015) & $15 \mathrm{~m}$ & $20 \mathrm{~m}$ & Clayey taste \\
\hline & $\mathrm{D}_{19}$ & $12^{\circ} 53537 \mathrm{~N}$ & $014^{\circ} 37992 \mathrm{E}$ & $288 \mathrm{~m}$ & 1,22 & 842 & 6,80 & 09,80(January 2013) & 07,90(January 2015) & $15 \mathrm{~m}$ & $20 \mathrm{~m}$ & Clayey taste \\
\hline
\end{tabular}

W: well; D: drilling; m: meter.

\subsection{Water Levels}

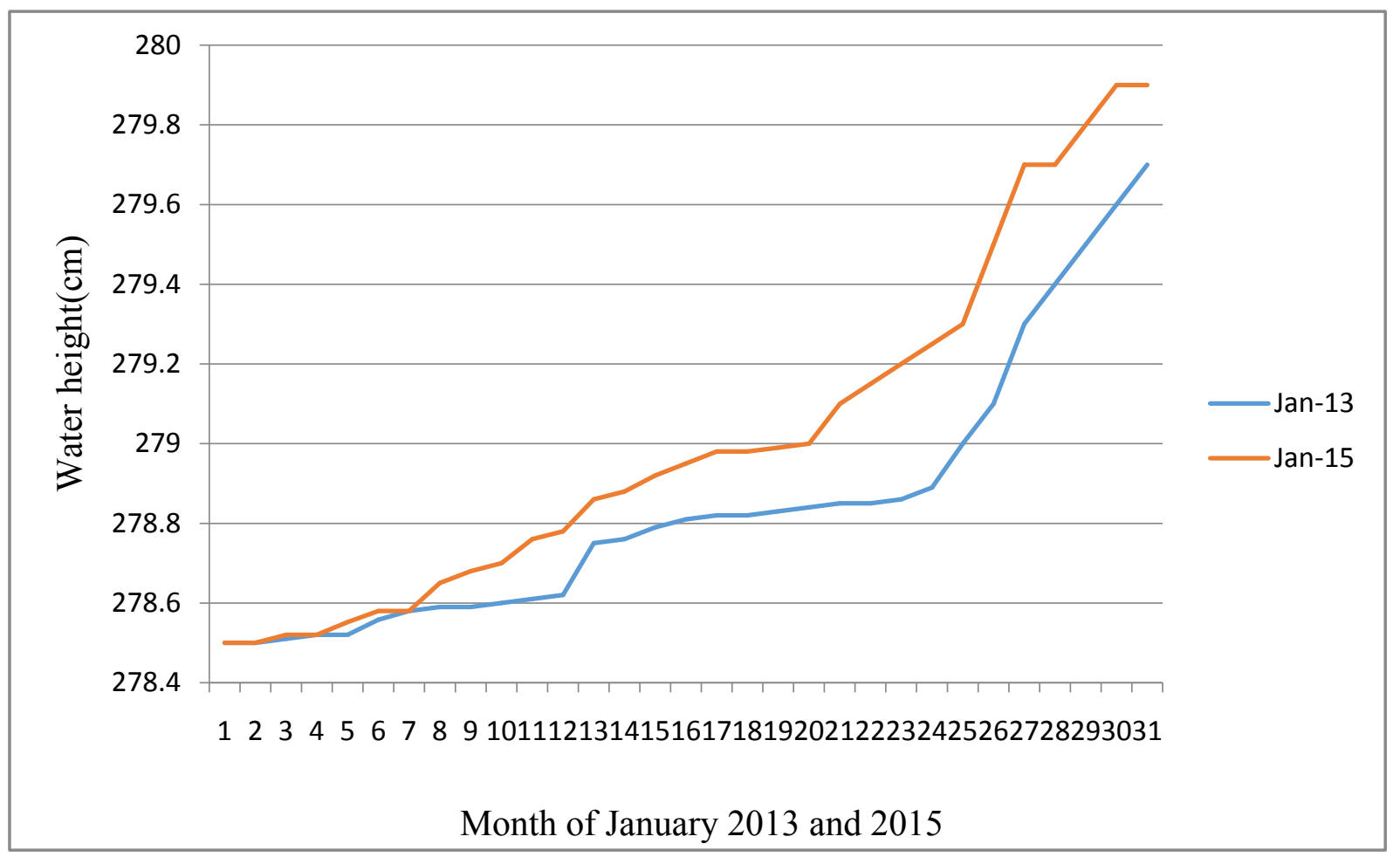

Figure 7. Full-month water levels at Bol in the months of January 2013 and January 2015 (SODELAC et al., 2015) 

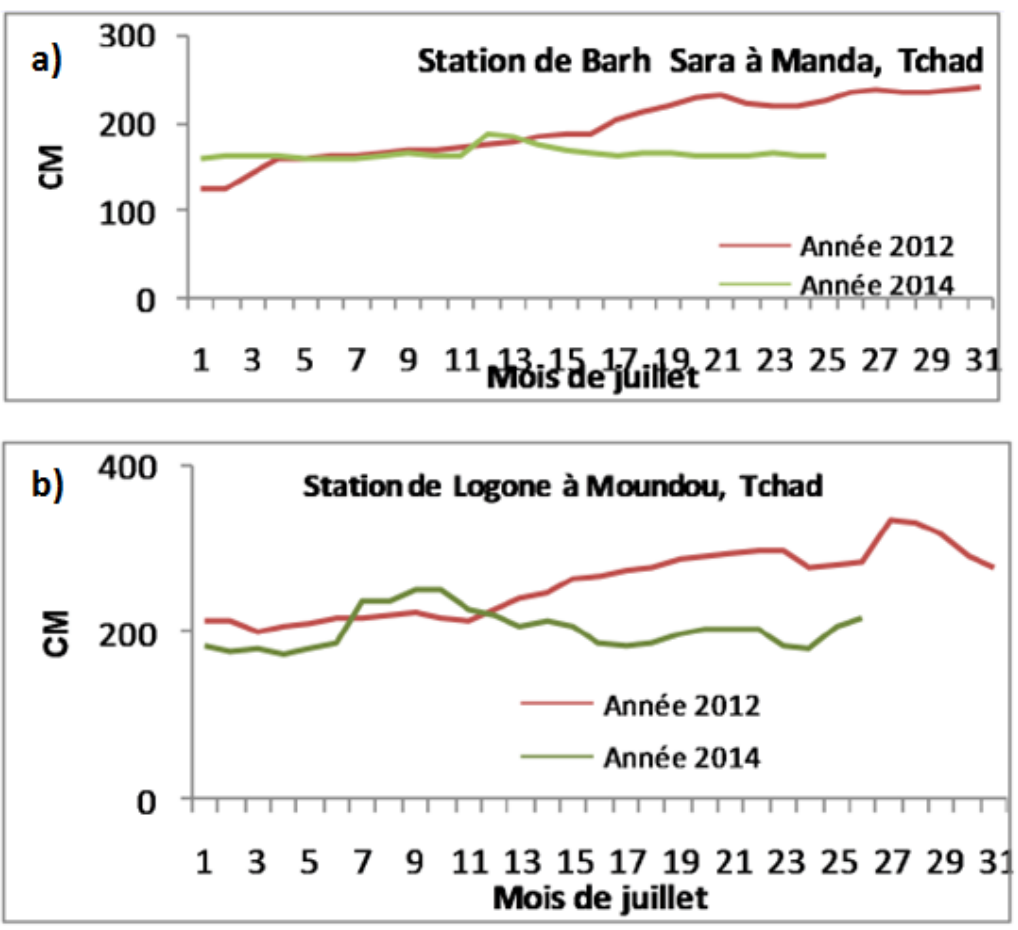

a) Barh Sara Station in Manda, Chad. (Month of July) (Red: year 2012), (Green: year 2014) (Month of July), b) Logone station in Moundou, Chad (Month of July)

Figure 8. Changes in the level of streams in the tributaries of Lake Chad in 2012, which experienced a river flood compared to the year 2014: a) Barh Sara station in Manda (Chari), B) Logone station in Moundou (Logone) (LaCBO 2014)

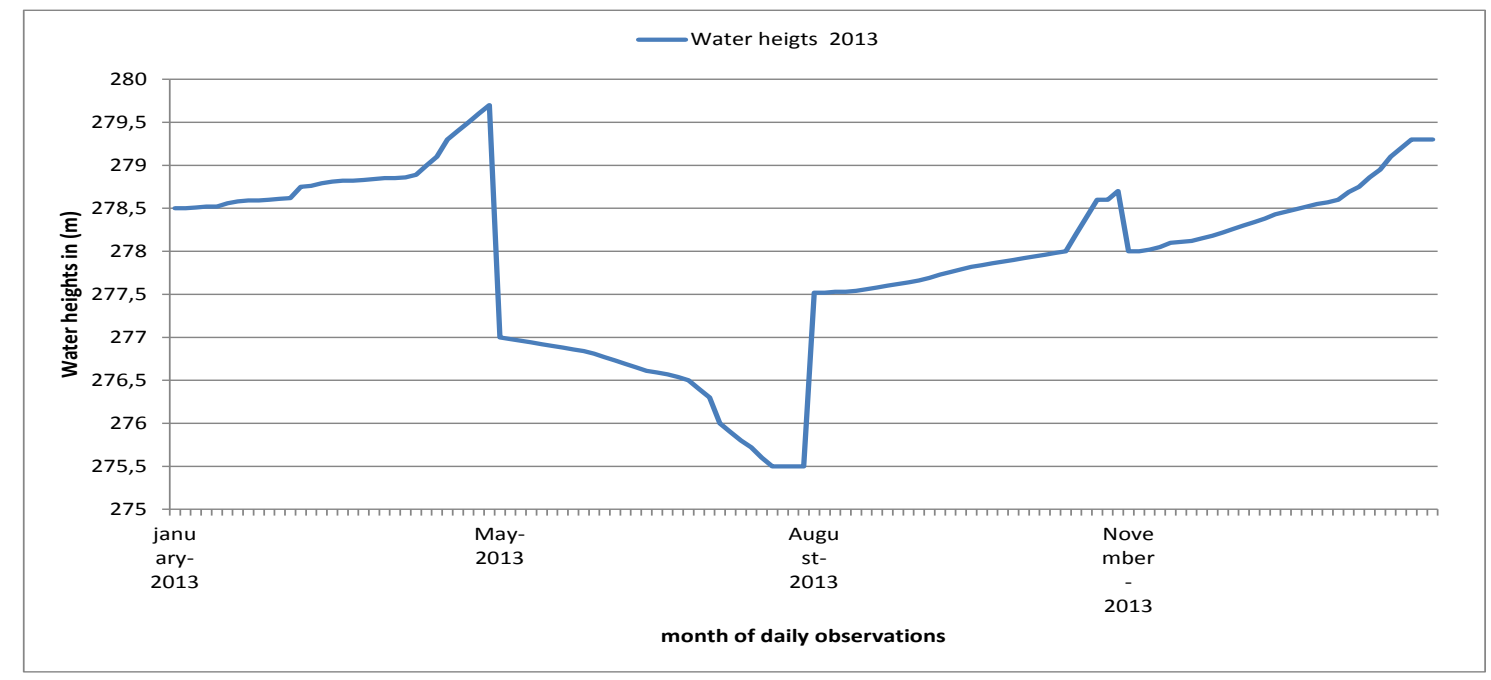

Figure 9. Daily variations of four months of the level observed at Bol of the year 2013. The altitude of the zero of the scale is at 275.5 meters

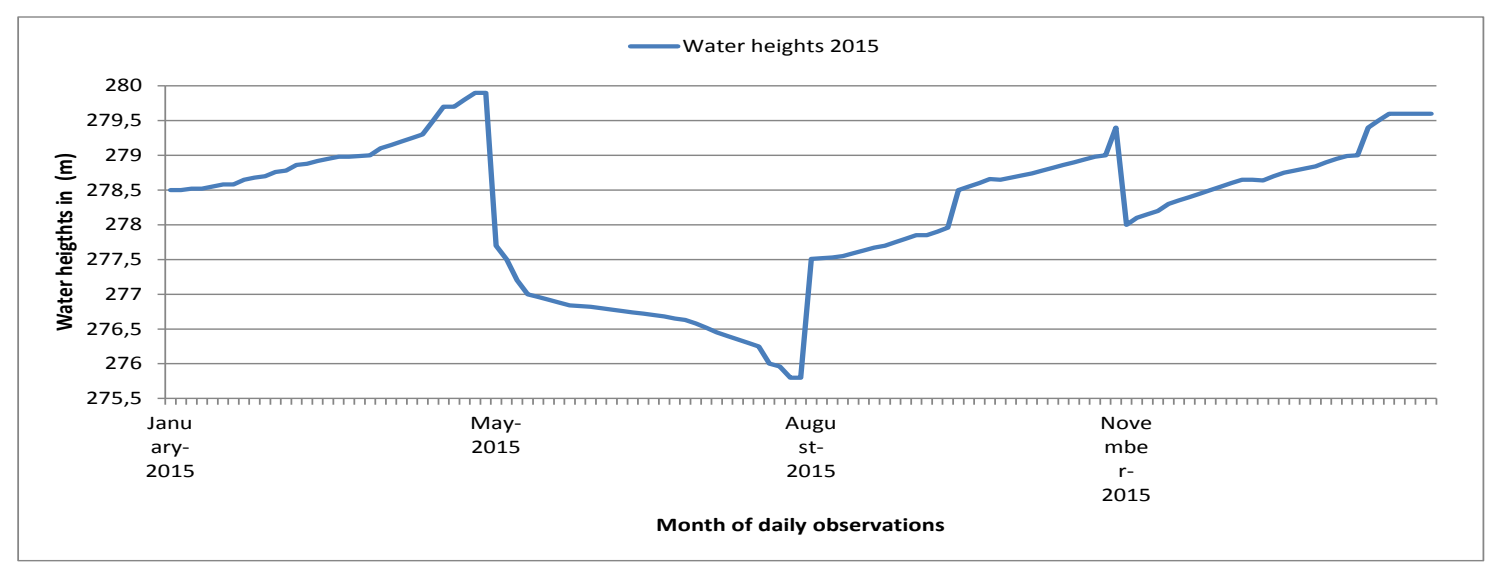

Figure 10. Daily variations of four months of the level observed at Bol of the year 2015. The altitude of the zero of the scale is at 275.5 meters 
3.2. Variation in the General Levels of the Free Water Table in the Study Area over a FourYear Period
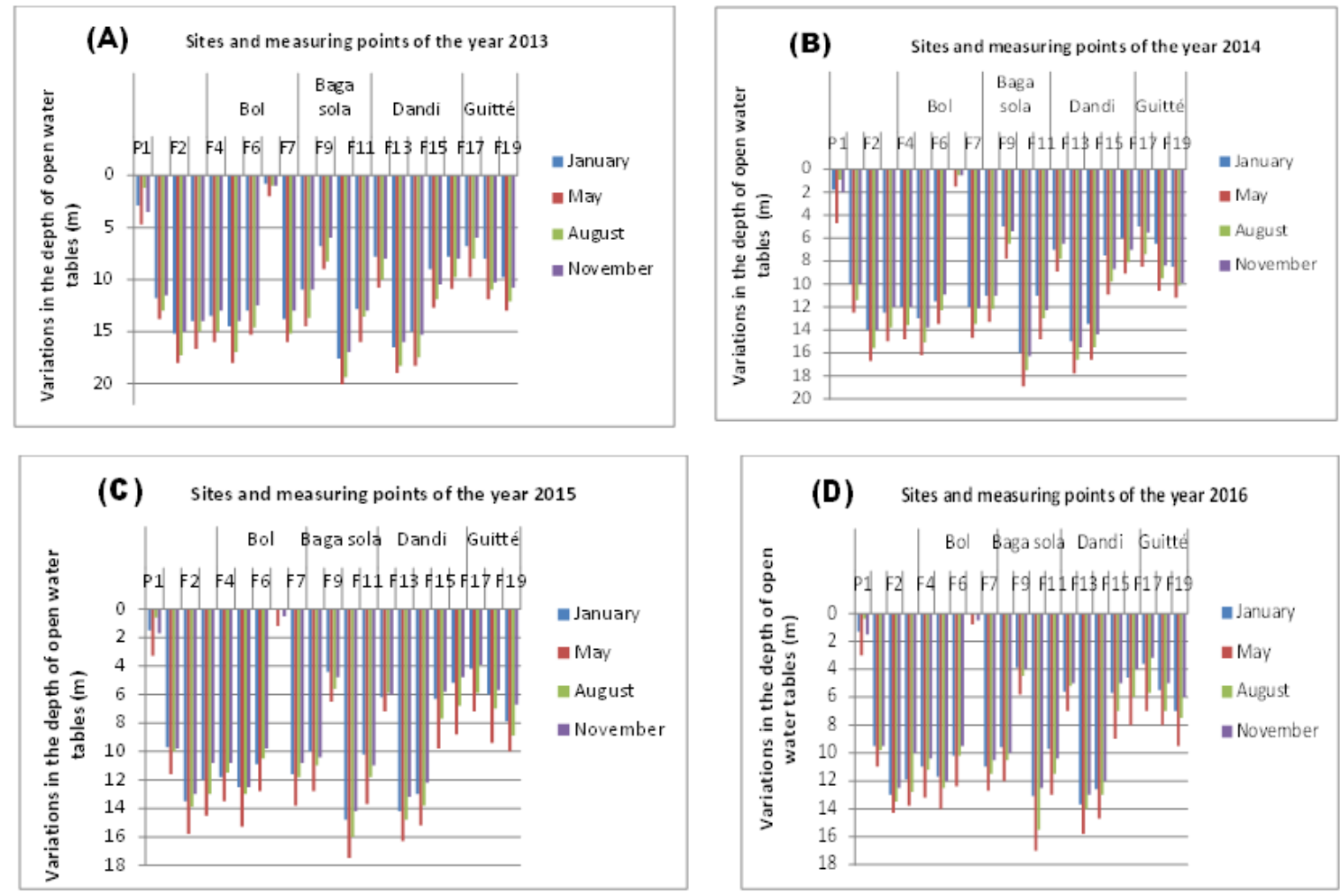

Figure 11. Spatio-temporal and inter-annual variation of the free water table in the study area (A: 2013, B: 2014, C: 2015, D: 2016)

\subsection{Variation of Free Water Levels in the Study Area over a Year}
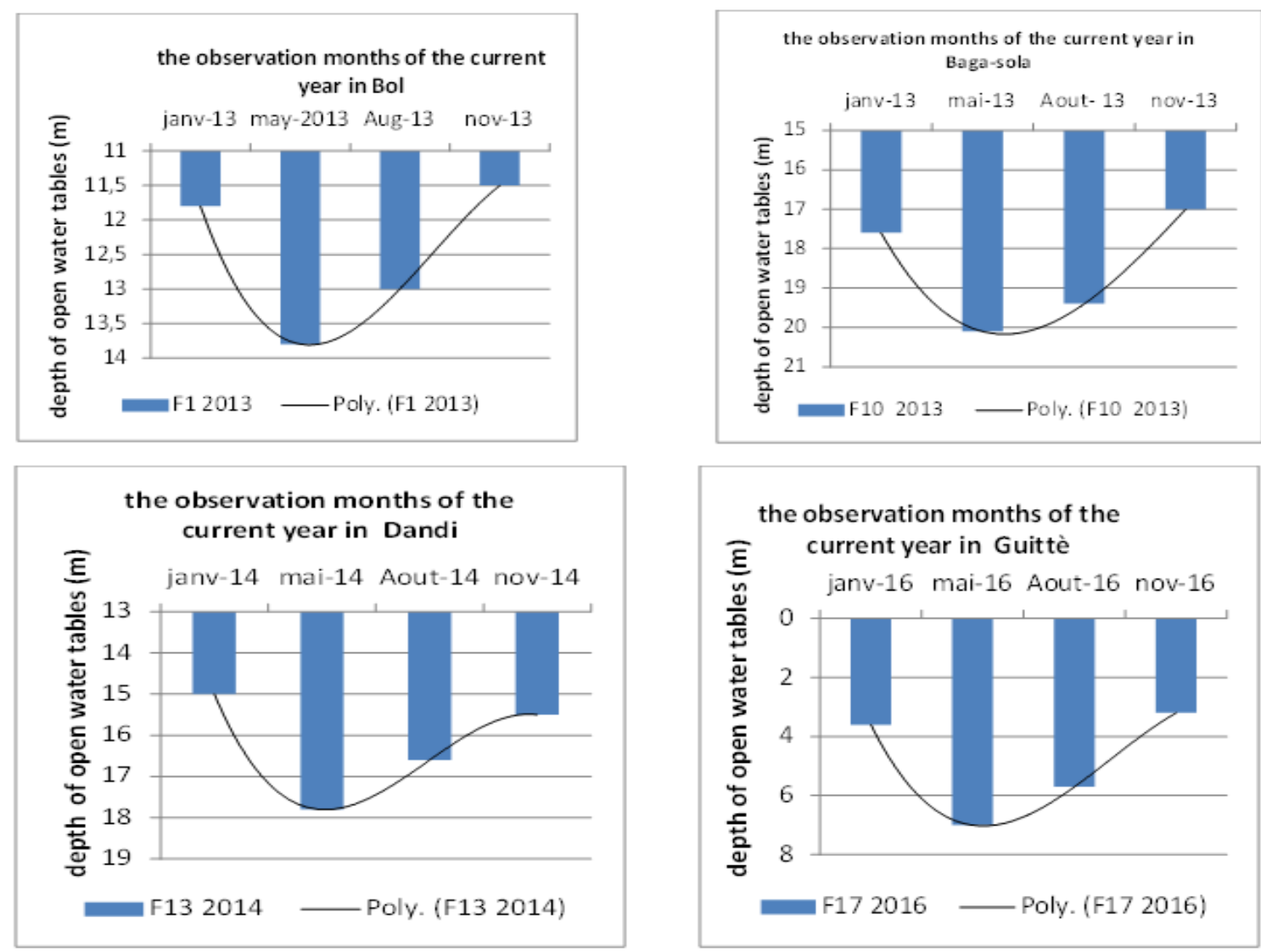

Figure 12. open water tables dynamics of the study area over a year: January, May, August and November on the different measurement sites (F1: Bol, F10: Baga-sola, F13: Dandi and F17: Guittè) 


\subsection{Variation in of the Levels of the Open Water Table in the Study Area over Four Years}
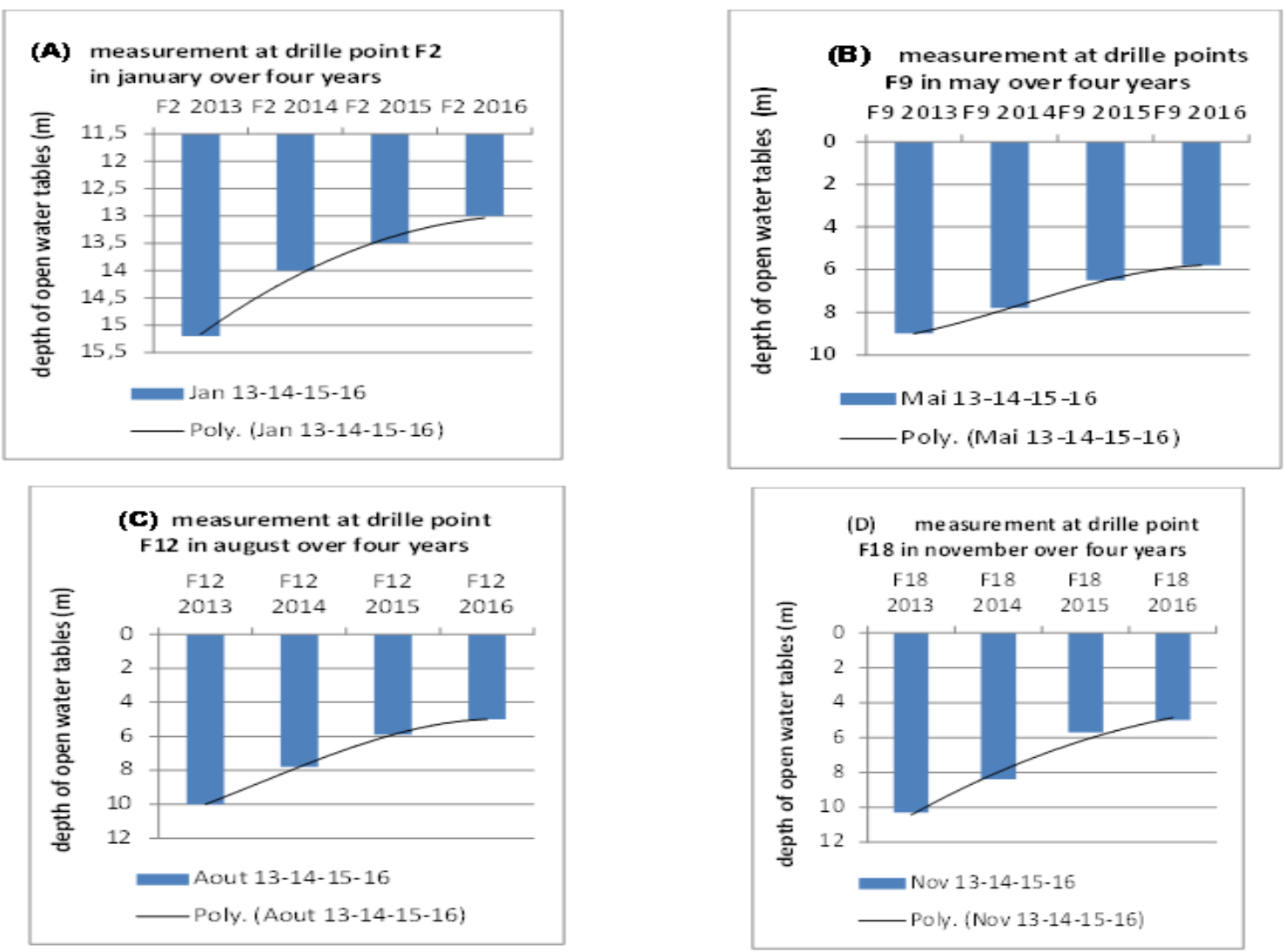

Figure 13. open water table dynamics of the study area of the same month over four years (A: January (F2: 013-2016), B: May (F9: 2013-2016), C: August (F12: 2013-2016) D: November (F18: 2013-2016))
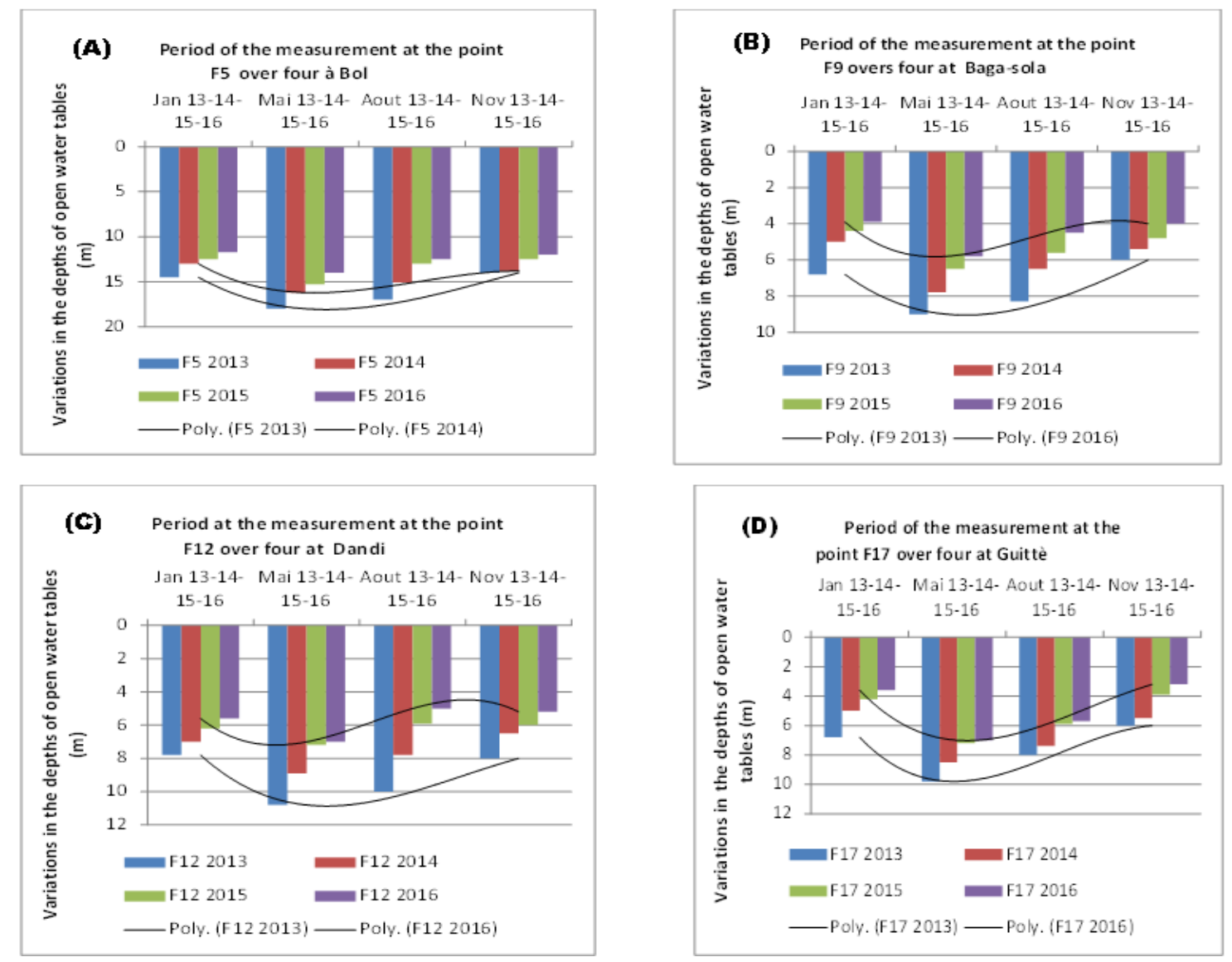

Figure 14. open water table dynamics of the study area from 2013 to 2016 of the observation sites: (A: Bol), (B: Baga-sola), (C: Dandi) and (D: Guittè) 


\section{Results Analysis}

\subsection{Description of the Upper and Recent Quaternary Formations}

A survey of measurements and observations, conducted at four sites on the southern shore of Lake Chad at the southern (Dandi and Guitte), north (Baga-sola) and northeast (Bol), (Figure 6), To study the water table of the upper Lake Chad formations over almost its entire thickness. The upper and recent quaternary aquifer, with a power of 20 to 80 meters depending on the sites, appears mainly composed of coarse, medium and fine sands. It can contain one or more lenticular clay layers 1 to 7 meters thick and rests on a probably Plio-quaternary impermeable clay wall [6].

As a result, the aquifers concerned in the study area are identified as follows: on the north and northeast side Baga-sola and Bol sites we have: the Ogolian sand aquifer with varying thicknesses between 20 and 80 meters, Upper Pleistocene age and groundwater is free, the phreatic aquifer of the area is fed, recharged directly by meteoric water much more in the mainland and lacustrine in the lake's boundary, because the permeability of the aquifer is High; The sand is renewed, this is of great importance in the conservation of surface waters of Lake Chad, the discharge is towards the northeast $[6,7]$.

And on the south side, the sites of Guitte and Dandi are the aquifers of the fluvial sands and clay intercalation, of medium and lower Pleistocene age, with rather compact thicknesses, the water table is open to semi-captive, here the permeability is Average, recharge of the aquifer is made by infiltration of surface waters and rain, the piezometric flow is towards the eastern depression in N'Djamena, evaporation and exploitation of the aquifer entail the discharge of the water, aquifer [7].

In addition to the aquifers mentioned, there are also different polder aquifers, silty lithological natures, diatomite clay masses, friable layers (hollow in wells), silty marls and finally lacustrine lower layers. The filling of the polders originates from the lake alone. The deposits are heterogeneous according to an installation mechanism obeying the flow and reflux of the lake. The polder aquifers are long, finger-like, with a width ranging from a few hundred meters to 1,500 to 2,000 meters. The level of the open water table of cracked clays varies according to rainfall, the influence of the lake, fed by mixtures of meteoric and lake water, and also by seasonal evaporation, the multiannual climate cycle and the structure of deposits [8].

The basic litho-stratigraphic observations essentially distinguish the different aquifers and hydrodynamic parameters (permeability and impermeability). The following lithostratigraphic sections (Table 2, Table 3 and Table 4 and Figure 15, Figure 16 and Figure 17) were observed at deep boreholes: from 77 meters at Baga-sola, 73 meters at Bol and 50 meters in Dandi and Guitte.

Table 2. Litho-stratigraphy observed at Baga-sola (ROCHE, 1982).

\begin{tabular}{|l|l|}
\hline Thickness (meters) & Lithology \\
\hline $0-0,2$ & Very fine structural material rich in organic materials \\
\hline $0,2-2,5$ & Grey-blue cracked clay, large permeable and aquifer \\
\hline $2,5-8,5$ & Greenish brown plastic clay or grey-blue \\
\hline $8,5-32$ & Fine sand aquifers \\
\hline $32-37$ & Same fine sand aquifers with white limestone pellets, up to $5 \mathrm{~mm}$ \\
\hline $37-47$ & Fine sand aquifers \\
\hline $47-62,5$ & Medium-sized fluvial sands, becoming increasingly coarser down \\
\hline $62,5-65$ & Hard clays, blue green, zoned with white powdery beds with a high proportion of limestone \\
\hline $65-77$ & Clays light green whitish, hard at the top then relatively soft. Probably the substratum. \\
\hline
\end{tabular}

The most complete cut on a drill of 73 meters observed in Bol

Table 3. Litho-stratigraphy observed at Bol (ROCHE, 1982).

\begin{tabular}{|l|l|}
\hline Thickness (meters) & Lithology \\
\hline $0-0,3$ & Very fine structural material rich in organic matter \\
\hline $0,3-4$ & Cracked blue gray clays. Constitute the aquifer with great permeability of the groundwater in the polders \\
\hline $4-5,5$ & Very soft plastic clay loams, brown grey \\
\hline $5,5-9$ & Fine sand aquifers contain an artesian aquifer in the polder \\
\hline $9-13$ & Blue gray clay, polyhedral; impermeable \\
\hline $13-69,5$ & $\begin{array}{l}\text { Fine and medium sands. Aquifers, contain an artesian water table in the polder. From about } 13 \text { to } 50 \text { meters: fine sands in which } \\
\text { appear about } 20 \text { meters of concretions of sands with carbonate cement of a few millimeters, with appearance of granules of } 50 \text { to } \\
69.5: \text { medium sands }\end{array}$ \\
\hline $69,5-73$ & Green clay, relatively hard, impermeable (lower clay layer), act as an impermeable wall of the water table. \\
\hline
\end{tabular}

Table 4. Litho-stratigraphy observed in Dandi and Guitte (SCHNEIDER, 1985)

\begin{tabular}{|l|l|}
\hline Thickness (meters) & Lithology \\
\hline $0-6$ & Sand \\
\hline $6-7,5$ & Sandy clay \\
\hline $7,5-19,5$ & Yellow sand \\
\hline $19,5-22,5$ & Sandy clay \\
\hline $22,5-41$ & White sand \\
\hline $41-41,5$ & Sandy clay \\
\hline $41,5-50$ & Pink sand \\
\hline
\end{tabular}




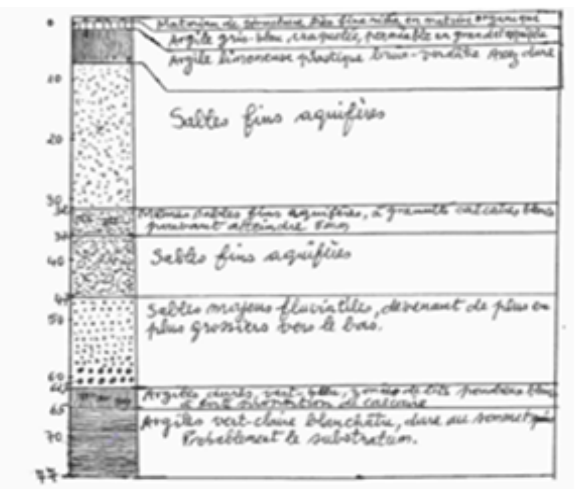

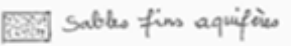

$$
\begin{aligned}
& \text { iii:iil Salles annjens aquifice. } \\
& \text { IIIII Argiles cenquebis aquifices } \\
& \text { Iidill Argies limoneuses imporméalles (dove) } \\
& \text { EArgiles imper méalles } \\
& \text { Argiles imperméables (dure) }
\end{aligned}
$$

Very fine structural material rich in organic materials Grey-blue cracked clay, large permeable and aquifer Very soft plastic clay loams, brown grey

Fine sand aquifers

Same fine sand aquifers with white limestone pellets, up to $5 \mathrm{~mm}$

Fine sand aquifers

Medium-sized fluvial sands, becoming increasingly coarser down

Hard clays, blue green, zoned with white powdery beds with a high

proportion of limestone Clays light green whitish, hard at the top then relatively soft. Probably the substratum.

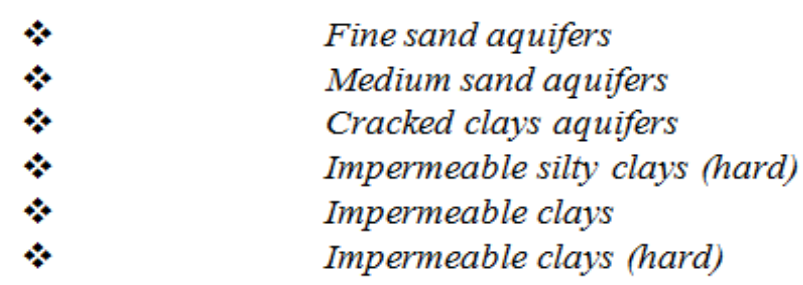

Figure 15. Litho-stratigraphic column observed at Baga-sola

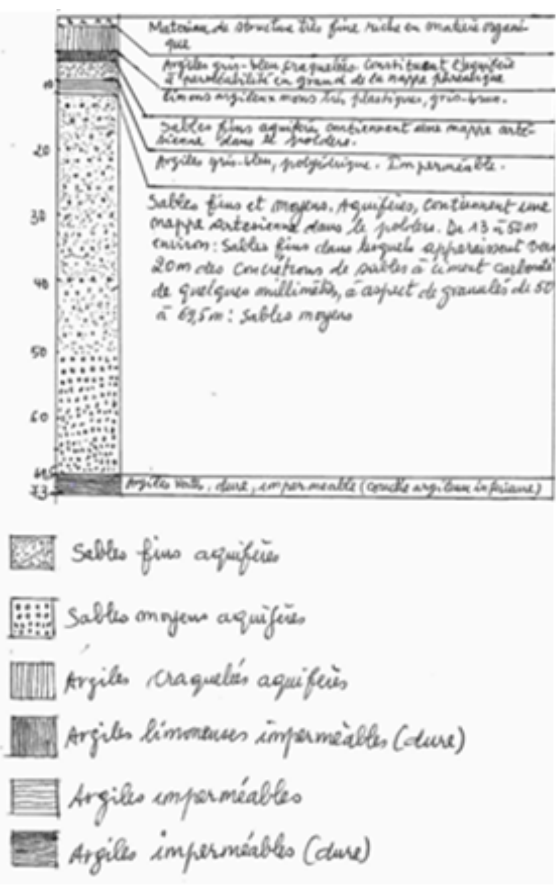

Very fine structural material rich in organic materials

Cracked gray-blue clays. Constituting the aquifer with large permeability of the water table

Very soft plastic clay loams, brown grey

Fine sand aquifers contain an artesian aquifer in the polder

Blue gray clay, polyhedral; impermeable

Fine and medium sands. Aquifers, contain an artesian water table in the polder. From about 13 to 50 meters: fine sands in which appear about 20 meters of concretions of sands with carbonate cement of a few millimeters, with appearance of granules of 50 to 69.5 : $\underline{\text { medium sands }}$

Green clay, relatively hard, impermeable (lower clay layer).

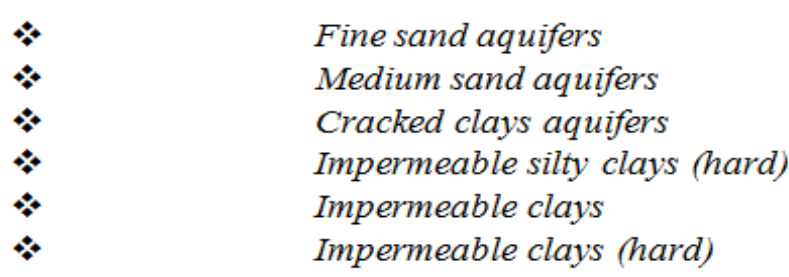

Figure 16. Litho-stratigraphic column observed at Bol 


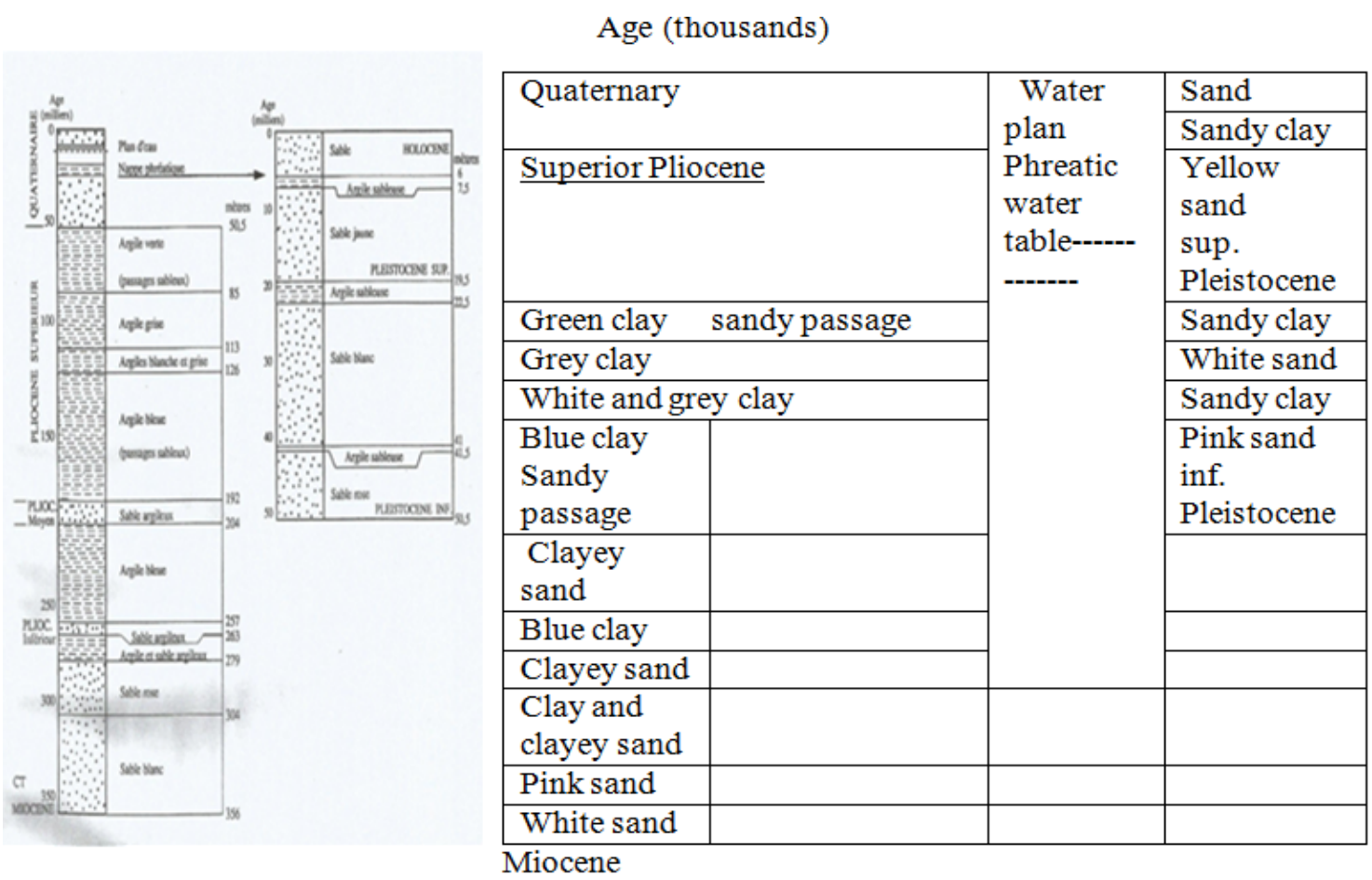

Figure 17. Litho-stratigraphic column observed at Dandi and Guitté

Clay formations: The lenticular nature of the clay unit constituting the bottom of the arms and its covering over a short distance by the dune was highlighted.

The material rich in organic materials, representing the cultivable soil of the polders, and the cracked clays, can be separated along the edges of the dunes by thin layer of sand. The silty clays which form the impermeable wall of cracked clays may not exist at the margins of the arms, thus putting the latter in direct communication with the underlying sands.

The lenticular nature of the intermediate clay layers encountered in the sands by their dispersion at different depths at varying thicknesses ( 2 to 5 meters). These formations bear witness to ancient inter-dunar basins that existed during the Quaternary at periods when the pattern of erg was in these regions more accentuated than at present [9].

The layer of light green clay, more or less hard, encountered at depths (63 to 70 meters), represents the impermeable wall of the whole aquifer.

Sands: The sands become slightly coarser down. The increase in grain size seems to occur suddenly at Bol and Baga-sola.

It seems possible to situate these different formations in the history of the Chadian basin thanks to the recent work of M. Servant (1976). The wind sands and the clay lenses that are disseminated there correspond to the sequence of the Soulias. The clays are the witnesses of lacustrine episodes some of which are between 40,000 and 21,000 years B.P. The higher clay unit of the polder bottoms corresponds to the Labde series. In the latter, the clay loams refer to the lacustrine sequence L1 (12,000-11,000 years B.P), the cracked clays of the L2 sequence $(10,000-$ 2,000 years B.P) [8].

The reservoir conditions can be summarized as follows: the underground water table rests on impermeable walls, located 69.5 meters in Bol and 65 meters in Baga-sola probably, the depth of the impermeable roofs, the water table is generally between 10 and 12 meters. Cracked clays are affected between 0 and 2.5 depending on the site (Figure 15, Figure 16 and Figure 17). Groundwater levels show daily variations: the period of these oscillations is very regular with a maximum occurring generally between 7 and 10 hours and a minimum between 18 hours and 20 hours, however these oscillations can be synchronized with the rising of the waters of the lake [7].

The aquifers are contained in medium sized aquifers, moving to finer sands. At least two or three lenticular layers of impermeable clays with varying thicknesses may exist in these sands at different levels. These clay formations isolate the water locally. Once the thickness of the clays is subtracted, the power of the water table varies [8].

This aquifer, called phreatic at the basin scale, is actually in the dunes and in the cracked clays of the polders where it is free. On the other hand, under the polder, the waters are loaded under the impermeable silty clays.

The water table of the cracked clays is itself in communication with the dune sands on the edge of the basins but also probably through the silty clays that support the underlying water table, although qualified as impermeable, the flow which over all their extent is certainly not negligible.

The flowing water and the lake therefore rest directly on this aquifer system [9].

\subsection{Water Levels}

The limnimetries installed at Bol are representative of the general level of the lake of the southern basin. The flood of Chari, of the pure tropical type, has a single wellmarked peak whose maximum is towards the end of October in N'Djamena. This peak of flooding occurs two months later in January in Bol (January 2013 (279.7 m), January 2015 (279.9 m)) (Figure 7), according to the January full follow-up.

The flood of the Chari and the Logone of the Year 2012 (Figure 8), for example, first fills the open water area of 
the southern basin, then the Bow archipelago and the north basin, the two basins are Separated by a large barrier which prevents the flow of Chari flowing water into the northern basin during periods of floods.

The amplitude of the variations in the level in the southern basin (open water) remains between 1.3 and 3.5 meters. Its average inter annual level remains between 280 meters. The inundation of the basin is dependent on the Chari flood and rainfall.

The changes in the level at Bol, represented by Figure 9 and Figure 10, show that the water levels are at the lowest levels in May, they begin to rise in August by the installation of rainy seasons and go back to the In November, by the arrival of runoff from tributaries (Chari and Logone), the months of January are the months when the water levels are at the highest levels in the lake.

Fluctuations of the lake annual variation level are characterized by a rise in water levels due to river intakes and precipitation. The maximum coastline is reached in January and decreased due to decreased intakes and evaporation (minimum in June). The importance of the lake's groundwater is due to a low amplitude of water levels, which allows the water table in the inter-dune valley to react to the inputs or the decrease. This is true in August with the rainy season and / or also with the general fluctuation of the water, multi-annual variations of the Chari flow indicating the reaction of the free water table in all the dune areas.

\subsection{Follow-ups of the Levels of the Slick at the Edge of the Lake and the Polders.}

A multidisciplinary study program on the conditions of sedimentation in the Chadian basin was carried out in the 1960 s and 1970 s by ORSTOM to understand the mechanisms of saline regulation of Lake Chad in an endoretic context. This work was the starting point of the studies which dealt with the relations between the groundwater table and Lake Chad, particularly in the Chadian part of the quaternary aquifer (Fontes et al., 1970, Maglione 1976, Chouret et al., 1977; ROCHE, 1980) [3].

- Piezometric evolution of the free water table at the edge of the lake: evidence of the impact of changes in the coasts of Lake Chad [7].

The lake rests in a position perched on the water table and thus represents a potential pole of recharge of the surface aquifer (UNDP-UNESCO-CBLT, 1972). Because of its large surface area, the lake plays an undeniable hydraulic role despite the variation in percolation capacities of the materials that cover its bottoms (Dupont, 1970) [10,11].

\subsection{Follow-up of the Free Surface Water Levels of the Upper and Recent Quaternaries on the Study Sites}

\subsubsection{Variation in the General Levels of Free Water in the Region Over a Four-year Period}

The piezometric follow-up to Bol-northeast, Baga-sola north, Dandi and Guitte south of the southern basin of Lake Chad from 2013 to 2016 show a spatio-temporal variation of the free water table (Figure 11).

The depths of free groundwater levels decrease from
2013 to 2016 (Figure 13). On the other hand, over a year, the depths of the aquifers oscillate: from the shallow in January, deep in May, decreases in August and at a depth substantially close to that of January of the measurement year in November (Figure 12).

Within this four-year measurement period, the southern basin of Lake Chad is well fed by the fluvial inputs of the Chari and Logone which are located in the Sudanian zone to tropical rainfall. This seems to have strongly influenced the water level of the lake (Figure 9 and Figure 10). We know that in 2007, the satellite image of NASA shows a rise of the coast of the lake. The southern basin is well fed, which leads, the northern basin is also again periodically submerged. The variable piezometric levels measured since 2013 to 2016 in the upper and recent quaternary aquifer of the southern basin of our study (Figure 11) can then correspond to this change in lake levels.

It should be noted therefore that the lake seems to be controlling the piezometric levels in a deferred manner. Furthermore, Leduc et al. (1998) report a piezometric drop of 3 to 8 meters between 1975/1976 and 1989 for a few wells near the lake. Then this study shows a variable, a rise of the piezometric levels on all the sites.

\subsubsection{Change in Free Water Table over a Year}

The variation over a year in the free-water dynamics of the upper and later Quaternary of the different measurement sites shows that the months of August and November are wet, this announces the rainy season in the region, whereas the month of May Is dry, which implies that the free water table withdraws deeply in this month of May; The depth begins to decline in August and is low in November, corresponding to the wet period of the year in the region (Figure 11 and Figure 12) [12].

\subsubsection{Change in Free Water Levels over a Four-year Period}

Dynamic monitoring of the free water table in the study area over four years at different drilling points shows a decrease in the depths of the free water tables from the year 2013 to 2016 , in all the points of the observation measurements. The year 2016 and wetter than the year 2013 (Figure 13 and Figure 14). Hydraulic gradients favor the infiltration of the lake into the sand aquifers (Figure 15) and the coastal polders, but the movements of water generated in this way must primarily concern the upper part of the aquifer, the piezometric level of the water table Region is less than the height of the lake water (Figure 18). Only the awareness of the isotopic compositions of the oxygen of the water molecules makes it possible to demonstrate water masses of different origins which do not always correspond to those which characterize the physicochemical study. Waters of meteoric origin mix with waters of lake origin after seeping into the sands. This mixture must in fact be realized gradually over time with an old basin of mainly lakes origin. The proportions of meteoric water thus increase regularly with the distance to the shore and decrease in depth. The infiltration of the lake's water has been demonstrated mainly in the axial direction of the exudate arms, or they gradually mix with the waters coming from the boundary dunes. The polders are finally fed by mixtures of water of both types in very variable proportions following the zones [6]. 


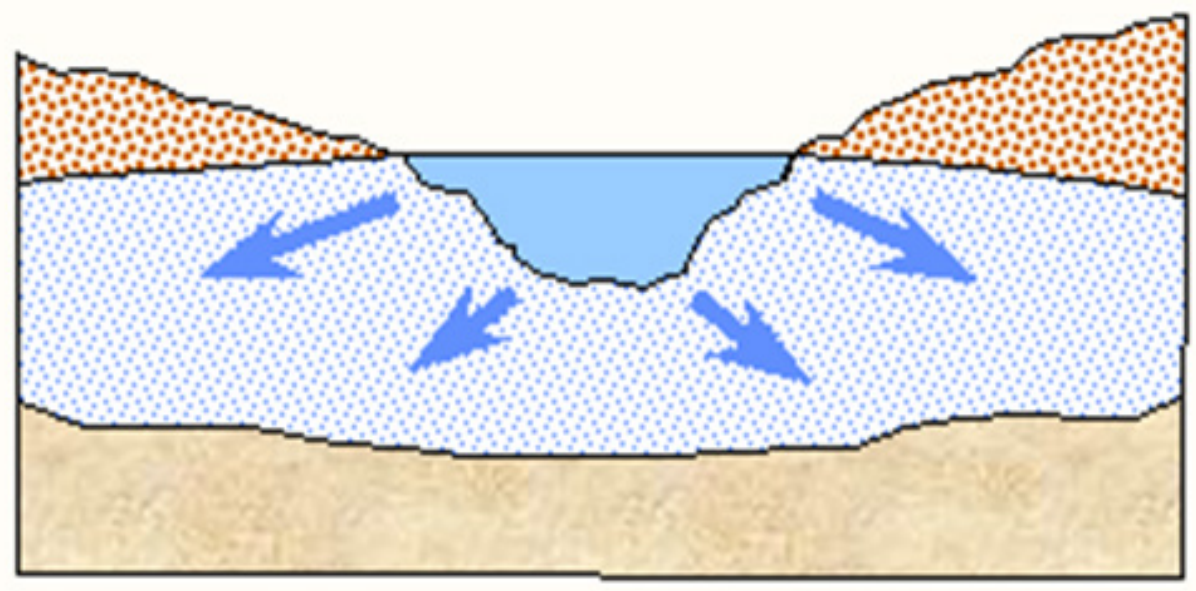

Figure 18. Alimentation of the free water table by the lake

The lake (high water) supplies the free water of the upper and recent Quaternary of the lake region, which is observed and obtained as results, the water level of the lake is higher than the piezometric level of the free water table of the superior quaternary and recent in the study area.

\section{Discussion}

Measurements from the coasts reveal a hydraulic gradient generally oriented inland to the piezometric depressions surrounding the lake [8].

Variations in the flow of the Chari cause the level of the lake to change in different surface areas, among others: in May 1874 at the coast 284.5 meters where the waters reached Remele, $110 \mathrm{~km}$ downstream of Massakory, the depth of the open water tables was at Less than a meter,

In July 1907, the coastline was less than 279 meters, where the northern part of the lake was dried up, the depth of the open water tables was at depths of about 20 meters, it is noticed that in its recent history The evaporation completely eliminated the lake (on the northern basin side) as a result of very low floods,

The present lake, whose existence is linked to the contributions of the Chari-Logone basin, the depth of the free water table in the lake region is less than twenty meters, the lake thus represents an average surface area of $20,000 \mathrm{~km} 2$, A vast expanse of $330,000 \mathrm{~km} 2$, which has been drying up for millennia [13].

The piezometric measurements made in June, May and August 1969 (Michel Alain ROCHE 1969), give the level of the lake varied from 4 to 3,2 of January the maximum to July the minimum, or around an average annual altitude of 281 , 5 meters (281-282), While Bader and al, 2011, give ; the lake level ranged from 3.5 to 2.1 around an average annual altitude of 280.5 meters $(280-281)$ [6,14],

The last observation gives the level of the lake which varies between 3.5 to 1.9 , around an average annual altitude of 280 meters (281-279).

\section{Conclusion}

The aquifer of the upper zone of the Lake Chad formations, described as phreatic at the level of the
Chadian basin, was examined on a thickness of 50 to 70 meters at four sites on the northern and northeastern coasts of the Chad Part southern basin of Lake Chad as well as south (Dandi and Guittè). Its relations with surface waters have thus been clarified.

The upper and recent quaternary aquifer, rests on an impermeable wall located at 69.5 meters at Bol and 70 meters at Baga-sola probably with also the same kinds of layers in even more depths (200 meters may be).

The aquifer circulates in sand of medium particle size, passing to finer sand. The latter constitute the erg of Kanem. At least two or three impermeable lenticular clay layers (mainly of the Soulias series), with a thickness of (1) one to seven meters, may exist at different levels. The thickness of the aquifer sand is variable at tens of meters. A part of the sand water flows into the cracked clays, which are largely permeable, which fill the polder bottoms (Labde series). This aquifer is isolated from the underlying sand by a layer of clay loams of very low permeability and its feeding is carried out essentially by its edges [9].

The lake, with an average level of 280 meters, extends over this complex.

For such a level of surface water, the medium piezometric gradients between the lake and the groundwater of the cracked clays are of the order of $3 \%$ [5] and oriented towards the mainland. Given the large thickness of the water table, it can be assumed that the water movements thus generated are mainly in the upper part. The sand slick is loaded under clay and locally artesian mudflats several tens of centimeters. The piezometric level of the groundwater of the polders undergoes oscillations, from two to three centimeters of amplitude and daily period, caused by the tidal wave $[6,11]$.

Only the isotopic compositions make it possible to highlight water masses of different origins and to specify the relations between the lake and the groundwater. On the shore of the lake, where the piezometric gradient is directed towards the interior of the lake, a steady decline in the proportions of lake water is observed in favor of meteoric water infiltrated through the dune. The preliminary conclusions, relating to the essentially meteoric origin of the upper part of the water table, are then confirmed. In the thickness, as evidenced by the few observations relating to Bol Nguini (polders located $15 \mathrm{~km}$ 
from the bank of the lake), the distribution of water is more complex; Following the same process, on the edge of polders adjacent to such dunes, rainwater mixes in decreasing proportions down to lake water. It is probable that the mixing has occurred progressively up to the present day with an essentially lacustrine origin [13].

The lack of data on groundwater resources in deep aquifers (Cretaceous-Pliocene) has become apparent. The acquisition of these data must be made through piezometric installations, followed by piezometric levels and the dating of these various types of water In order to specify their dynamics, so this will eventually make a research protocol.

\section{Acknowledgements}

I strongly thank the "Support Project for Higher Education" which financed this thesis work for my travels in the field, my stays in Dakar at Cheikh Anta Diop University in Dakar.

My thanks goes also to the SODELAC (Development Society of Lake Chad), the personal administrations of N'Djamena who have always facilitated my trip to Bol, those of Bol I am very grateful for their welcome, guidance and especially their great help in The data collections that were so valuable, without them this work will not be finalized.

I very sincerely thank Maloud Raymond, my thesis supervisor, for supervising this work. I thank him for his advice, for his invaluable help in the drafting of this thesis.

I would like to express my sincere thanks to Serigne FAYE for her wise guidance and her readiness, that I am grateful for his valuable human qualities, his interest in this work and his administrative support.

I also thank Abdoulaye FAYE for his administrative help during my pre-registration.

I would like to thank KODI Mahamat Mbam and SOUK ALLAG Waayna for agreeing to read and corrected this document.

I especially thank my family and my parents for the trust they gave me and who believed in me during this period.

At Bol and Baga-sola, where I had a good time. I thank ABOU Mamadou Malloum and Mallah Mamadou Malloum for their help during the field missions as well as the whole family Mamadou Malloum in Bol.
Without forgetting the teachers and the personalities of the Department of Geology of the Faculty of Science and Technology of Cheikh Anta Diop University of Dakar.

\section{References}

[1] Leblanc, M. J., Leduc, C., Stagnitti, F., van Oevelen, P. J., Jones, C., Mofor, L. A., Razack, M., Favreau, G., 2006 a. Evidence for Megalake Chad, north-central Africa, during the late Quaternary from satellite data. Palaeogeography, Palaeoclimatology, Palaeoecology, 230 (3-4): 230-242.

[2] Chouret, A., Mathieu, P., 1976. Groundwater at the periphery of Lake Chad: Preliminary results of recent work by ORSTOM. IIIrd Conference of African Geology. Khartoum, Sudan. January 1976, p. 7-17.

[3] Chouret, A., Fontes, J.C., Mathieu, P., 1977. The water table on the periphery of Lake Chad. ORSTOM / FAC, 11, 67 p.

[4] Marc Leblanc, Guillaume Favreau, Sarah Tweed, Christian Leduc, Moumtaz Razack \& Linus Mofor, 2006, Remote sensing for groundwater modeling in large semiarid areas: Lake Chad Basin, Africa 15: 97-100.

[5] BOUCHEZ Camille, 2015, Doctoral thesis: Assessment and dynamics of river-lake (s) -aquifer interactions in the Lake Chad hydrological basin - Coupled geochemical approach and transfer modeling. 296p.modeling

[6] ROCHE Michel Alain, 1982, Hydrogeology of the coasts of Lake Chad at No, Tchingam and Soro (Kanem). 28p.

[7] J.-L. SCHNEIDER (B.R.G.M), 1985, Relation between Lake Chad and the groundwater (Republic of Chad) $.5 \mathrm{p}$.

[8] Schneider, J.L., Wolff, J.P., 1992. Geological map and hydrogeological maps at 1/1 500000 from the Republic of Chad, Explanatory memorandum BRGM, 209. Orléans, France.

[9] Servant, M., Servant-Vildary, S., 1973. The Plio-Quaternary of the Lake Chad Basin. Scientific Research National Center. Conference Proceeding. Quaternary, geodynamics, stratigraphy and environment. 1973, p. 169-175.

[10] Maley, J., 2004. The basin of Lake Chad in the recent Quaternary: sedimentary formations, palaeoenvironments and prehistory. The question of Palaeotchads. In: J. Renault-Miskovsky and A.M. Semah (Eds.), Guide to World Prehistory, p. 179-217.

[11] Pias, J., 1970. The tertiary and quaternary sedimentary formations of the Chadian basin and the soils derived therefrom. Paris, Orstom, Mem. Orstom, 43, 407 p.

[12] Leduc, C., Sabljak, S., Taupin, JD, Marlin, C., Favreau, G., 2000. Estimation of Quaternary groundwater recharge in the northwestern Lake Chad Basin From isotopic measurements. C. R. Acad. Sci. Paris IIa, 330: 355-361.

[13] Massuel, S., 2001. Hydrodynamic modeling of the Quaternary water table of the Lake Chad Basin. Memory DEA. University of Montpellier II - University of Avignon and the Vaucluse countries. $82 \mathrm{p}$.

[14] ZAIRI Rim, 2008, Doctoral thesis: Geochemical and hydrodynamic study of the free water table of the Lake Chad Basin in the regions of Diffa (Eastern Niger) and Bornou (northeastern Nigeria). $169 \mathrm{p}$. 